OPEN ACCESS

Edited by:

Erik Andersson,

Stockholm University, Sweden

Reviewed by:

Perrine Hamel,

Stanford University, United States

Angelina Sanderson Bellamy,

Cardiff University, United Kingdom

${ }^{*}$ Correspondence:

H. M. Tuihedur Rahman tuihedur.rahman@dal.ca

Gordon M. Hickey

gordon.hickey@mcgill.ca

Specialty section: This article was submitted to

Land Use Dynamics,

a section of the journal

Frontiers in Environmental Science

Received: 01 October 2018 Accepted: 04 January 2019

Published: 22 January 2019

Citation:

Rahman HMT and Hickey GM (2019) What Does Autonomous Adaptation

to Climate Change Have to Teach

Public Policy and Planning About Avoiding the Risks of Maladaptation in Bangladesh? Front. Environ. Sci. 7:2.

doi: 10.3389/fenvs.2019.00002

\section{What Does Autonomous Adaptation to Climate Change Have to Teach Public Policy and Planning About Avoiding the Risks of Maladaptation in Bangladesh?}

\author{
H. M. Tuihedur Rahman ${ }^{1,2 *}$ and Gordon M. Hickey ${ }^{1 *}$ \\ ${ }^{1}$ Department of Natural Resource Sciences, Faculty of Agricultural and Environmental Sciences, McGill University, \\ Ste-Anne-de-Bellevue, QC, Canada, ${ }^{2}$ School for Resource and Environmental Studies, Dalhousie University, Halifax, NS, \\ Canada
}

Climate vulnerability represents a highly complex public policy challenge for government due to its interaction with diverse social, political, economic, and ecological factors across scale. The policy challenge is further exacerbated when rural livelihood opportunities depend on multiple land use practices within shared social-ecological systems and adaptation actions related to one practice affects the others. In such cases, it becomes likely that national and regional-level adaptation plans will result in maladaptive trajectories if local context and properties are not carefully considered. This review highlights the importance of this issue to public policy using the case of climate change adaptation planning in Bangladesh to highlight how national and regional-level planned adaptation processes could benefit from paying closer attention to the autonomous adaptation processes occurring at local levels. Focussing on the northeastern floodplain region, an area dominated by wetland ecosystems, high climate vulnerability, and diverse and complex land use practices, we examine some of the community-level adaptation actions that are being undertaken in response to climate change and contrast these with national-level adaptation planning strategies and actions. We then analyze how the planned adaptation actions taken by government may actually end up being maladaptive, either by shifting or rebounding vulnerability. We conclude that government adaptation planning would benefit from a greater focus on learning and scrutinizing the autonomous adaptation of communities to climate stress before making significant resource allocation decisions.

Keywords: adaptation mainstreaming, livelihoods, land use, rural landscapes, sustainability, natural resource management, public policy

\section{INTRODUCTION}

Bangladesh is often considered to be one of the most climate vulnerable countries in the world. Climate vulnerability represents a highly complex and dynamic public policy challenge for government due to its interaction with diverse social, political, economic, and ecological factors across scale (Adger et al., 2005) that results in context-specific interpretations of what climate 
vulnerability looks like (Jurgilevich et al., 2017). Despite this complexity, both the government of Bangladesh and affected communities are taking many actions to help support climate adaptation (Rahman et al., 2018a). As noted by Huq and Rabbani (2011), Bangladesh has been one of the few developing countries to show significant progress toward climate change adaptation planning and community-level adaptation practices internationally. This is reflected by a growing recognition and incorporation of climatic uncertainties in national-level policy making processes and local-level development practices (Ayers J. et al., 2014; Ayers J. M. et al., 2014).

Of particular importance in Bangladesh is the vulnerability of rural livelihoods ${ }^{1}$ to climatic stresses. Agrarian land use practices offer livelihood opportunities to the majority rural population of the country, although per capita arable land availability is only $0.05 \mathrm{ha}-$ one of the lowest in the world. Access to land resources is therefore highly contested, with a range of poverty, socioeconomic discrimination and inefficient resource entitlement issues affecting the social-ecological landscapes (Rahman et al., 2014, 2018a). Importantly, there is highly variable knowledge available to government agencies working to address climate vulnerability across the country. For example, Miah et al. (2011) and Rahman et al. (2018a) noted that certain regions of Bangladesh tend to receive higher priority in public policy than others due to vested political interests, highly visible climatic impacts (e.g., extreme loss of life and property), significant scientific research attention, and media coverage. Since it has been argued that climate change and its impacts will likely reduce a state's capacity to provide opportunities and services for affected people (Barnett, 2003), and curtail rural communities' capability to respond to climate impacts (Tompkins and Adger, 2004; Smit and Wandel, 2006; Morton, 2007), it becomes important to carefully scrutinize how national adaptation policies are responding to local climate vulnerability. Of particular concern here is the potential for imbalanced information and knowledge to lead to flawed adaptation plans and inequitable distribution of scarce resources, leading to maladaptive trajectories (Barnett and Adger, 2007; Ayers J. et al., 2014).

Beyond policy-driven adaptation actions, it is also important to recognize that the climate-affected communities of Bangladesh are developing their own local innovation-based adaptation actions (Rahman et al., 2018c). Although, these innovations are often challenged by local resource availability and access politics, learning from and promoting these "grassroots" innovations has the potential to avoid government policy-driven maladaptation. However, such learning would require an intensive assessment of local adaptation practices in different contexts to help inform national-level adaptation plans, an effort that is rarely prioritized alongside existing scientific knowledge production processes in Bangladesh. Therefore, the main objective of this review is to identify what the national adaptation planning processes of

\footnotetext{
${ }^{1}$ The Intergovernmental Panel on Climate Change (IPCC) define livelihoods as “... the ensemble or opportunity set of capabilities, assets, and activities that are required to make a living' IPCC (2012). Managing the risks of extreme events and disasters to advance climate change adaptation. Cambridge: Cambridge University Press.(2012, p. 798).
}

Bangladesh can learn from context-specific and local innovationbased adaptation practices in order to reduce the risk of maladaptation. Focussing on the northeastern floodplain region of the country, an area dominated by wetland ecosystems, high climate vulnerability and diverse and complex land use practices, we ask what community-level adaptation actions are being undertaken by local communities in order to inform nationallevel adaptation planning processes. We particularly focus on this area because of its unique geographic features, seasonality of climate change impacts, underexposure in scientific literature, and lack of media attention (Miah et al., 2011; Rahman et al., 2018a).

In what follows, we present the conceptual background to our review, followed by a general background of rural livelihood vulnerability issues in Bangladesh. We then narrow our focus to the northeastern floodplain region to analyze the adaptation policy context and identify relevant government initiatives to facilitate local livelihood adaptation with a view to assessing the potential for maladaptation drawing on both peer-reviewed scientific and non-peer-reviewed 'gray' literature and policy documents. We conclude the paper by offering insights for public policy and future adaptation planning initiatives.

\section{DEFINING VULNERABILITY AND ADAPTATION}

Climate vulnerability is defined as '.... the degree to which geophysical, biological and socio-economic systems are susceptible to, and unable to cope with, adverse impacts of climate change' (IPCC, 2007). Although this definition seems straightforward, the assessment of vulnerability can be influenced by diverse conceptual framings which will influence adaptation planning (Rodima-Taylor et al., 2012). Burton et al. (2002) and Füssel and Klein (2006) identified two broad framings of vulnerability assessment: "science-based" and "human dimension-based." "Science-based" vulnerability assessment primarily focuses on causes (e.g., greenhouse gas emission trends and impacts) and consequences (e.g., long and short-term climate variable change forecasting) of climatic change, and informs the exposure of a society or sector to specific climate impacts. This framing of vulnerability helps policy makers to identify physical and technological actions to minimize the negative impacts of climate change. In contrast, "human dimension-based" vulnerability assessment takes account of social, economic, ecological, policy, and governance systems, in order to provide a more contextualized understanding of vulnerability (O'Brien et al., 2007). Adaptation decision-making under this vulnerability framing tends to be more complex and challenging because different sectors and communities are not considered equally vulnerable to different climate change impacts. As a result, adaptation-related decision-making generally requires an assemblage of the diverse perspectives of affected communities in order to make resource distribution trade-offs.

IPCC (2014) defined adaptation as "the process of adjustment to actual or expected climate and its effects." 
Rodima-Taylor et al. (2012) suggested that adaptation needs to be innovative and knowledge-based, while knowledge can be fostered by establishing and extending learning networks across scales, societies, and institutions (Bidwell et al., 2013). Fankhauser et al.'s (1999) framing of adaptation suggests that adaptation actions can be either reactive and autonomous or anticipatory and planned. Reactive and autonomous adaptation actions are the spontaneous ex post interventions taken in response to an undesirable climate event. These actions are most often based on immediate and localized problem determination, and require the right information, knowledge, skill and incentives, which are necessarily cross-scaler and dynamic (Fankhauser et al., 1999; Malik et al., 2010). However, Engle (2011) cautioned that these adaptation actions might become trapped in a maladaptive trajectory if a balance between cross-scaler interactions and contextual subjectivity (i.e., culture and social goals) is not maintained. Anticipatory and planned adaptation actions, on the other hand, are large scale, predictionbased and goal-specific ex ante actions (Fankhauser et al., 1999; Smit et al., 2000). Most of these adaptation actions are taken by government and private actors, for which the development of a broader knowledge-base and capacity to predict future events is considered a primary requirement (Engle, 2011). In the case of rural livelihood adaptation, many researchers link planned adaptation to rural development, assuming that poverty is one of the main barriers to climate change adaptation. As a result, Ayers J. et al. (2014) called for greater integration of climate change adaptation in development policies and institutional processesa concept widely known as "adaptation mainstreaming." Despite the growing recognition of adaptation mainstreaming, ensuring social justice and social-ecological integrity remains perhaps the biggest challenge because the prioritization of adaptation actions and their implementation processes are necessarily subjected to political and economic considerations. This has led to a recognized need for national-level adaptation planning processes to become more meaningfully informed by locally-practiced and innovated "autonomous" adaptation processes (Fazey et al., 2010).

Given the risk of enhancing inequitable resource distribution and socio-economic insecurity, adaptation planning in the absence of required knowledge and information may lead to “maladaptation," defined by Barnett and O'Neill (2010) as “action taken ostensibly to avoid or reduce vulnerability to climate change that impacts adversely on, or increases the vulnerability of other systems, sectors or social groups." They go on to identify five types of maladaptation: (i) increased greenhouse gas emissions due to adaptation actions; (ii) obtaining adaptation for one sector or community at the expense of other sectors' or communities' increased vulnerability; (iii) high social, economic and environmental opportunity costs arising from adaptation actions; (iv) encouraging unnecessary dependence on others, encouraging rent seeking behavior, and reducing incentives to adapt; and (v) path-dependent development (Barnett and O'Neill, 2010). Juhola et al. (2016) conceptually separated maladaptation from unsuccessful implementation of policy implementation arguing that while a policy may fail to obtain adaptation or reduce vulnerability, if it enhances vulnerability and reduces the capacity to adapt, the policy may lead to maladaptation. Emphasizing the multiple drivers and spatiotemporal dimensions of maladaptation (Magnan et al., 2016), Juhola et al. (2016) advocate for an ex ante analysis noting that adaptation policy measures may result in three types of maladaptation: (i) rebounding vulnerability (increasing climate exposure and sensitivity and reducing adaptive capacity of the communities for whom adaptation measures have been planned); (ii) shifting vulnerability (transferring the negative impacts of adaptation measures to someone not considered by the adaptation measures); and (iii) eroding sustainable development (common pool problems). Notably, all three types of maladaptation are strongly tied to the institutional, technological and resource use, and distribution approaches of a society and its government. This suggests that both planned and autonomous adaptation actions need to be critically assessed under the conceptual framework of maladaptation in order to help identify which adaptation actions serve societal needs in the long run while also maintaining social justice, equity, and social-ecological integrity.

\section{VULNERABILITY OF LAND USE-BASED RURAL LIVELIHOODS IN BANGLADESH}

Bangladesh is located just below the Himalayan mountain range, with a number of trans-boundary rivers that originate in the Himalayas traveling through the country before discharging in the Bay of Bangla (Mirza, 2002). Due to its low topographic features, riverain land forms and its location in the monsoon climatic region, Bangladesh experiences diverse climate change impacts that include flood, cyclone, oceanic surges, saline water intrusion, sea-level rise, drought, and ground water depletion (Karim and Mimura, 2008; Shahid and Behrawan, 2008; Alauddin and Sarker, 2014). Recent studies indicate that the frequency, extent and duration of these climatic phenomena have intensified since the 1980's (Ali, 1999; Mirza, 2002; Ahmed and Ahmed, 2003; Karim and Mimura, 2008; Islam et al., 2014; Nowreen et al., 2014; Kay et al., 2015). Facing diverse climatic impacts, it is getting harder for both the government and affected rural communities to support and promote sustainable socio-economic development (Alam et al., 2011). Nevertheless, Bangladesh has instituted a number of significant adaptive responses to climatic impacts in both policy and practice, although much remains to be done (Rawlani and Sovacool, 2011; Ayers J. M. et al., 2014; Islam et al., 2014).

Drawing on meteorological perspectives (Füssel, 2007; O'Brien et al., 2007), many studies have characterized the nature of climate change impacts and estimated their impacts on rural land use-based livelihood activities, including agriculture and wetland fisheries in Bangladesh (Karim et al., 2012; Rahman et al., 2012; Rajib and Rahman, 2012; Hossain and Teixeira da Silva, 2013; Rabbani et al., 2013; Hasan et al., 2014). At the same time, these studies have forecast future climate change scenarios at national and sub-national scales contributing significantly to national policy processes (Nowreen et al., 2014; Kay et al., 2015). For example, Begum and Fleming (2009) 
and Mirza (2002) predicted that sea level rise and increasing river water discharge due to global warming will change and alter the natural flood dynamics in Bangladesh, and that this will influence agricultural land use and other rural economic activities. It has also become increasingly clear that climatic events have been changing, with impacts shifting from one region to another (Shahid and Khairulmaini, 2009). As a consequence, many land resource dependent communities in rural Bangladesh have been experiencing unfamiliar climate impacts.

The socio-economic properties of rural Bangladesh include poverty, disproportionate distributions of livelihood resources and socially-embedded political marginalization, generally maintained by insufficient and often inefficient institutional systems at local levels (see for detail Rahman et al., 2014, 2015; Haq and Ahmed, 2016; Szabo et al., 2016; Alam, 2017; Islam, 2017). In relation to rural livelihoods, resource distribution and access are considered particularly important because resource ownership enhances the capacity of affected communities to take adaptive actions (Ribot, 2014). For example, Pouliotte et al. (2011) observed that the land use decisions of small-scale land owners in the southern coastal region of Bangladesh often depended on the decisions of larger-scale land owners, potentially undermining the adaptation actions of poorer households. In such cases, small-scale landholders move to urban areas to shift their livelihood practices, subsequently losing control over land resources, and becoming potential victims of urban climate vulnerability (Adri and Simon, 2017). In addition, Pouliotte et al. (2011) observed that climate impacts like water stagnancy and saline water intrusion are altering the land and resource qualities in Bangladesh, resulting in a dynamic change in rural land use practices. Most rural communities who have historically depended on agricultural land use for their livelihoods are now diversifying their livelihood practices to reduce risks (Ahsan et al., 2011; Kartiki, 2011). As a consequence, a widespread shift in land use practices, increased rural-urban migration and employment in non-natural resource dependent livelihood activities is occurring (Pouliotte et al., 2011; Hassani-Mahmooei and Parris, 2012; Etzold et al., 2013).

\section{ADAPTATION PLANNING IN BANGLADESH}

In response to the increasing intensity of climate change impacts, Bangladesh has been gradually developing climate adaptation plans and mainstreaming climate-sensitive adaptation actions in its national development policies, with support from international climate change action forums (Ayers J. et al., 2014). The National Adaptation Plan of Action (NAPA) and the Bangladesh Climate Change Strategies and Action Plan (BCCSAP) form the foundation of national-level adaptation planning in Bangladesh, with both originally inspired by the decisions and actions taken by the United Nations Framework Conventions on Climate Change (UNFCCC).

The development of NAPA resulted from the 7 th Conference of Parties (COP) 2001, held at Marrakesh to help guide the adaptation actions to be taken in the 51 Least Developed Countries [Ministry of Environment and Forests (MoEF), 2005].
As of 2017, all 51 countries had developed their respective plans, with Bangladesh a pioneer of the process. The central agenda of NAPA was to identify and design immediate and priority activities for which further delay would potentially increase the vulnerability of the country. As mandated in COP 7, the NAPA planning process in Bangladesh followed 10 guideline elements outlined by the LDC Expert Group (LEG) (UNFCCC, 2001). These guidelines prioritized that the plan would be consistent with the sustainable development goals of every country, and therefore, wider participation of stakeholders was required. The NAPA planning team in Bangladesh subsequently recruited diverse stakeholder groups from different levels of the government, civil society, and affected community representatives in order to identify 15 priority activities in the form of projects to be implemented immediately after the planning process. These activities were broadly framed under two types of measures: intervention type ( 8 projects) and facilitating type (7 projects) measures. While the first type of activities were designed to take physical adaptation actions (e.g., afforestation, coastal flood protection infrastructures, promoting salt tolerant crop varieties etc.), the second type activities were aimed at developing institutional infrastructure, capacity building, scientific research, and developing knowledge networks [Ministry of Environment and Forests (MoEF), 2005].

The BCCSAP is the more comprehensive and updated national adaptation plan with a 10 -year implementation period. It was developed under the guidelines of the Bali Action Plan, also known as the COP 13 held in 2007 (Rai et al., 2014). The Bali Action Plan (2007) acknowledged deficiencies in NAPA requirements, and mandated a long term global goal of emission reduction based on national capacity, international cooperation for urgent adaptation actions, technology development and transfer to enhance emission reduction, and enhancing financial arrangements for the implementation of adaptation and mitigation actions in developing countries. In response to these mandates, BCCSAP was developed building on six priority areas covering 44 programs. These priority areas include: (i) food security, social protection, and health (9 programs); (ii) comprehensive disaster management (4 programs); (iii) infrastructure (8 programs); (iv) research and knowledge management (7 programs); (v) mitigation and low carbon development (10 programs); and (vi) capacity building and institutional strengthening (6 programs) (MoEF, 2009). In order to ensure financial support for implementing the plans, the government established funding mechanisms supported by both the national government and international donor agencies (Huq and Rabbani, 2011). Bangladesh's intention to combat climaterelated impacts has also been well-reflected in the National Sustainable Development Strategy, 2010, and in other more recent development plans in almost all sectors [Ministry of Planning (MoP), 2010].

In general, both plans envisioned the need to identify adaptation deficits and intended to locate potential sectors and regions where adaptation supports are necessary (Ayers and Huq, 2009; Ayers J. et al., 2014). Despite the advances, the national development and adaptation plans have been heavily criticized because of their generalized 
nature, insufficient contextualization, and the inadequate and inefficient incorporation of affected communities' knowledge and viewpoints in the planning processes (Parvin and Johnson, 2015; Tashmin, 2016). Further, there has been a general lack of adequate science and policy interaction in the policy and planning process leading to incongruences and significant knowledge gaps (Haque et al., 2017; Rahman et al., 2018a). As a result, it is difficult to prioritize which adaptation actions need to be taken in what area, and despite the growing number of scientific studies, it remains difficult to ascertain the extent to which usable and salient knowledge is available to decisionmakers (Cash et al., 2002; Lemos et al., 2012; Ford et al., 2013; Lalor and Hickey, 2014; Rahman et al., 2018a).

\section{CLIMATE CHANGE IMPACTS IN THE NORTHEASTERN FLOODPLAINS}

The northeastern floodplain is one of the most climate vulnerable parts of Bangladesh because of its geographic location, climatic properties and ecosystem dynamics (Miah et al., 2011; Haque et al., 2017; Rahman et al., 2018a). This area is bordered by Assam and Meghalaya mountainous territories and receives the highest rainfall in Bangladesh (Nowreen et al., 2014). The area also falls under one of the most complex trans-boundary river systems in South Asia, known as the Barak river tributary [Ministry of Water Resources (MoWR), 2012]. A total of 23 trans-boundary rivers flow through the floodplain, and serve as the main ecological driver of the wetland dominated ecosystem of the area. These wetlands are locally known as haor, which are enriched with natural resources and biodiversity [Ministry of Water Resources (MoWR), 2012; Figure 1]. According to the Bangladesh Haor and Wetlands Development Board, haors are the bowl-shaped depressions of considerable aerial extent lying between natural levees of rivers or high lands of the northeast region of Bangladesh [Ministry of Water Resources (MoWR), 2012]. In most cases haors have been formed as a result of peripheral faulting leading to the depressions. There are 373 haors in the northeastern floodplain covering an area of 858,460 ha. During the monsoon period, most of the wetland areas are submerged, while water remains only in some permanent depressions in the dry season [Ministry of Water Resources (MoWR), 2012]. These depressions serve as habitat for fish resources, while agriculture is extensively practiced in the higher land areas. A large number of populations directly or indirectly depend on these haors for their primary livelihood activities, most of which are land use based (Rahman et al., 2015).

The floodplains are prone to seasonally distributed climate impacts including: seasonal flood (late July-early November), flashflood (late March-early April), over rainfall (late May-late August), and drought (late February-late March). Monsoon seasonal flooding - the other natural property of this ecological system-is acerbated by high river waterflow as a consequence of extreme rainfall in the bordering upstream Indian provinces including Assam and Meghalaya-some of the wettest places in the world (Kamal et al., 2018). Ahmed et al. (2017) reported six flashflood events to have taken place in this region between 2000 and 2017, with model-based scenarios suggesting an increased future frequency of flashflood events (Nowreen et al., 2014; Masood and Takeuchi, 2016).

Local biophysical changes arising from natural and anthropogenic processes are also intensifying the climate change impacts in the area. Brown and Nicholls (2015) and Johnson and Alam (1991) noted that the northeastern floodplain naturally deposits lower amounts of sediments compared to other parts of the country, and that the subsidence rate is also higher than most other parts of the country. However, sediment flow and sand deposition on river beds are intensifying due to upland forest destruction and hill cutting for urbanization and natural resource extraction (Choudhury and Nishat, 2005; Rahman et al., 2011; Uddin et al., 2013). Moreover, extensive non-permanent embankment building for the protection of dry season rice crops is trapping sediments in river beds, resulting in water congestion during the monsoon and water storage capacity reduction during the dry season (Brown and Nicholls, 2015; Rahman et al., 2018b). These anthropogenic and natural factors are contributing to long term and persistent flood problems, and also enhancing water unavailability in the dry season, a situation compounded by prolonged drought and temperature increase (Nury et al., 2017).

The socio-economic structure in this region also contributes to climate vulnerability. The wetland resource-dependent communities are subjected to extreme poverty and economic marginalization (Ahmed et al., 2008). In particular, economic inequality is extremely high in the area, dividing the resident communities into two contrasting economic groups, influencing political power differentials and reducing the capacity of poor households to access land resources for their primary livelihood activities (Khan and Haque, 2010; Rahman et al., 2012). Most of the population in the area depends on agriculture for their primary livelihood, despite landlessness being a common feature (Rahman et al., 2015). Landless or extremely poor farmers depend primarily on shared cropping systems [Ministry of Water Resources (MoWR), 2012]. Fisher groups tend to be particularly marginalized, driven by government fisheries resource management policies that make it difficult to obtain property rights, and force them to seek livelihoods in the agricultural sector as laborers (Khan and Haque, 2010; Rahman et al., 2012, 2015).

Wetland uses in the northeastern floodplains are divided in two seasons: dry (November-April) and monsoon (MayOctober). Dry season is the most productive land use period, providing land for the extensive cultivation of irrigation-fed winter rice (also known as Boro rice) and winter vegetables (Rahman et al., 2018b). Most productive fishing from shallow land depressions also occurs during this season (Rahman et al., 2015). As a result, the dry season provides livelihood opportunities for most households. Monsoon, on the other hand, is considered the "lean" season in terms of land use and locally available livelihood opportunities. Open access fishing is the only major locally-available livelihood activity during this season along with limited access to agriculture in the highlands of bordering villages near some wetlands (Rahman et al., 2018c). However, winter crops and fishing are highly vulnerable to 


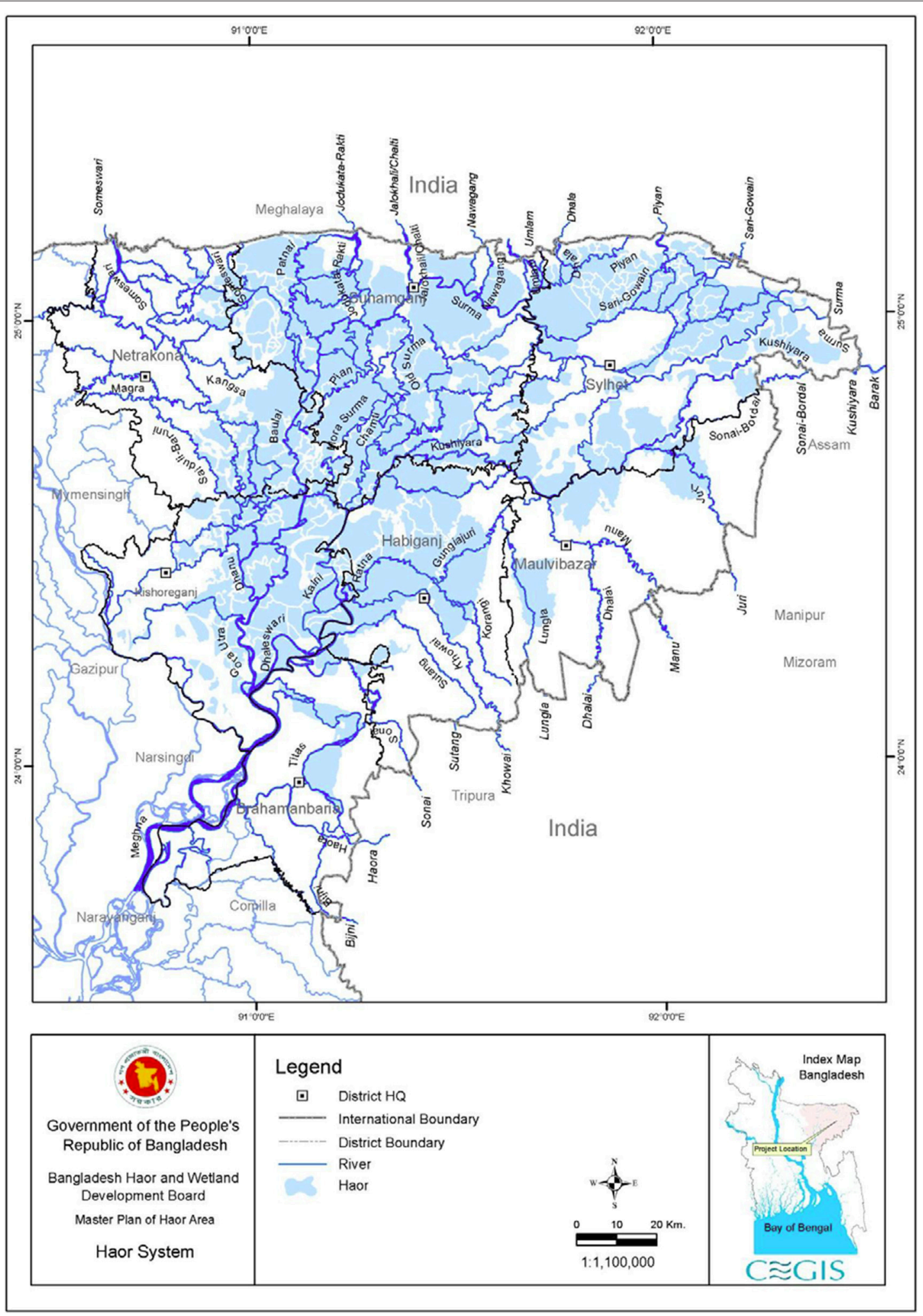

FIGURE 1 | Haor areas of the northeastern floodplain of Bangladesh [Source: (Ministry of Water Resources (MoWR), 2012)]. 
flashflood and drought events, while prolonged seasonal flooding also affects winter crop plantations by congesting water (Haque and Jahan, 2015; Rahman et al., 2018b). In particular, the impacts of floods and other climate events are most abruptly felt by socioeconomically and politically marginalized communities such as women, indigenous communities, and poorer segments of society (Kamal et al., 2018; Rahman et al., 2018c).

\section{PLANNED ADAPTATION IN THE NORTHEASTERN FLOODPLAIN}

Climate change adaptation has been nurtured and mainstreamed in the national policy making processes of Bangladesh. As a result, the planned adaptation decisions and actions being taken for the northeastern floodplain have been facilitated and/or affected not only by internationally-guided adaptation planning (e.g., NAPA and BCCSAP) but also by other national and regional-level development plans and activities. These different processes have directed the planned adaptation actions in the floodplain region in three ways: (i) "hard" infrastructure development through engineered construction projects designed to extend physical protections against climate change impacts (e.g., embankment, drainage systems, sluice gates); (ii) "soft" technology-based adaptation actions designed to generate locally-available adaptation options (e.g., diversifying land use practices, alternative livelihood opportunities); and (iii) institutional capacity building to respond to local adaptation needs.

Due to the high frequency of seasonal flood and flashflood events resulting from the complex and extensive river networks that pass through the floodplain, most planned adaptation activities in this region aim to minimize the negative impacts of flooding. In particular, these activities seek to protect human settlements from flood and Boro rice plantations from early flashflood events. For example, the BCCSP, which is funded by international and specialized national funds and implemented through government and non-government collaboration, includes a priority program for maintaining and repairing embankments that were previously developed for flood protection (Huq and Rabbani, 2011). However, the highest investment for embankment building comes through the government's Annual Development Programme (ADP), which is primarily implemented by the Bangladesh Water Development Board (BWBD). Examples of engineered large-scale projects being implemented include: intervening for flood control and drainage, land reclamation, river dredging, compartment-dyke building, river bank protection, sluice gate building, digging canals, and building and maintaining submersible embankments. Some of these projects are specific to the northeastern floodplain (e.g., Kalni-Kushiara River Management Project, Upper SurmaKushiara Project, Flashflood Protection and Water Drainage Project in Haor Areas, Haor Flood Management and Livelihoods Improvement Project and the Re-excavation of Bemalia and Balvadra Rivers under Bramhanbaria and Habiganj Districts), while others are part of national flood management programs (e.g., Char Development and Settlement Project and Water
Management Development Project). The Master Plan of Haor Area (MPHA), 2012, a long-term and multi-sectoral regional development plan, has also designed four short- and longterm flood protection infrastructure projects to be implemented between 2012 and 2032 with an approximate cost of USD 212.45 million [Ministry of Water Resources (MoWR), 2012].

The "soft" technology-based adaptation actions are smaller in scale and generally involve technology dissemination to facilitate local livelihood activities and generate alternative livelihood options. For example, NAPA had two adaptation projects designed to help support agriculture and fisheries sectors at a cost of USD12 million. The major activities under these projects involved expanding potato cultivation in the northeastern floodplain and promoting aquaculture [Ministry of Environment and Forests (MoEF), 2005]. BCCSAP also had two programs designed to enhance the livelihood resilience of communities living in ecologically critical areas and other vulnerable socioeconomic groups, although detailed descriptions were not reported in the planning document (MoEF, 2009). The MPHA identifies a number of projects involving technology transfer to improve agricultural land use (e.g., diversifying crop varieties, changing cropping pattern, expanding household level vegetable gardening, surface water irrigation, pest control technology, and training, etc.) and fisheries resource management (e.g., establishing fish sanctuaries), which are yet to be implemented [Ministry of Water Resources (MoWR), 2012]. Although these projects have not been directly designed for climate adaptation, they will have direct impacts on community-level adaptation.

Institutional capacity building projects are mainly designed to develop the knowledge base related to climate change and its impacts on different sectors and geographic locations. Another objective of these projects is enhancing the policy capacity of government agencies to incorporate and execute climate adaptation actions in their respective plans and policies. For example, NAPA identified seven research and capacity building projects of which three projects were designed to build the institutional capacity of government, while the other projects focused on research aimed to develop drought and flood tolerant crop varieties [Ministry of Environment and Forests (MoEF), 2005]. The direct outcome of these projects has been climate change adaptation mainstreaming in sectoral and regional policies and plans. The Bangladesh government has maintained its pursuit of adaptation mainstreaming in the subsequent adaptation plan-BCCSAP, proposing six programs under a capacity building and institutional strengthening theme (MoEF, 2009). These programs broadly seek to advance adaptation in national, spatial and sectoral development plans, enhance human resource capacity building within the government to better respond to emerging climate change issues through training, better understand, and manage gender issues related to climate change and promote media attention toward climate change impacts in order to build community awareness. However, a considerable shift toward prioritizing research is evident in the BCCSAP, which identifies the need to systematically develop subnational climate change models and measure climate impacts on biodiversity, ecosystem, and socio-economic systems (MoEF, 2009). The completion of the northeastern floodplain's wetland 
classification and climate model development projects under the MPHA is perhaps the most recent example of local-level knowledge generation [Ministry of Water Resources (MoWR), 2012].

\section{AUTONOMOUS ADAPTATION IN THE NORTHEASTERN FLOODPLAIN}

Climate affected communities, in the absence of their capacity to organize planned adaptation actions, intervene with spontaneous responses to climate impacts. These spontaneous responsesalso known as autonomous adaptation-are usually based on how the affected communities perceive and frame their vulnerability to climate change. Frank et al. (2011) and Safi et al. (2012) posited that community perceptions are motivated both by scientific information about any particular impact and community members' direct experiences with stress events (Midtgaard and Madsen, 2018). Community members, therefore, tend to interpret information based on the intensity of the climate impacts, their subjective experience of the impacts, their memories surrounding those experiences and their capacity to respond (Frank et al., 2011; Wachinger et al., 2013). In the case of land use dependent rural livelihood vulnerability, Sánchez-Cortés and Chavero (2010) and Bele et al. (2013) have linked local climate impact perceptions to livelihood practices, cropping patterns, seasonality and cultural practices, findings which have also been echoed by Midtgaard and Madsen (2018) in the case of the northeastern floodplain communities. Further, by taking account of both the climatic (e.g., the frequency, extent and duration of stresses) and nonclimatic factors (e.g., social, cultural, economic, geographic), Rahman et al. (2018b) identified that non-climatic factors play a major role along with climatic factors in constructing community perceptions toward climate change impacts. For example, community members in the floodplain feel more exposed to climate change impacts if they have fewer livelihood opportunities, an over-dependence on natural resources, high crop diversity, low crop rotation, and crop losses due to climatic and non-climatic factors (Rahman et al., 2018b). However, they do not pay equal attention to flood, drought or rainfall intensity, frequency or duration to explain their exposure to climate change impacts (Gray and Mueller, 2012; Rahman et al., 2018b). Instead, a community's longstanding experience with seasonal stresses actually allows that community to more specifically identify which extreme climatic events are the potential stresses to land use-related livelihood activities (Rahman et al., 2018b). Recognizing that affected communities' framings of vulnerability are guided by both climatic and non-climatic considerations is therefore key to understanding which socio-economic factors can serve to maintain local livelihoods through "grassroots" innovation processes that draw on local, traditional, and/or indigenous knowledge systems.

Building on their own vulnerability framing, community members mobilize their available resources for autonomous adaptation. These resource mobilization strategies can be better understood using the capital assets approach described in the Sustainable Rural Livelihoods (SRL) framework (Chambers, 2006), which states that household assets are used to diversify livelihoods rather than invest them all into a single activity. Since most natural-resource-dependent livelihood activities (e.g., fisheries, agriculture) in the study area are sensitive to climate change impacts, the livelihood vulnerability literature posits that a balance between natural and non-natural resource-dependent activities (e.g., wage earning, small business, migration) should help maintain livelihoods (Cinner and Bodin, 2010; Cinner et al., 2012). In the northeastern floodplain, household capital assets are used for collective action-based organization development and to diversify livelihoods through fishing, farming, livestock rearing, overseas and in-migration for jobs, small business enterprise, and seasonal business (Monwar et al., 2014). The community members use their peer networks and kinship for developing small-scale community organizations. These organizations help them generate financial resources through collective saving, which they further distribute among the members as loans at a lower interest rate than conventional sources (e.g., bank and microcredit organizations) (Rahman et al., 2018c). These organizations also help them to access government subsidized small-scale agricultural technologies (e.g., tractors, harvesters, thrashers, irrigation pumps etc.) and fishing rights (for more detail on government subsidized technology dissemination and fishing rights, please see Rahman et al., 2012, 2018c). However, as noted by Rahman et al. (2018c) and Rahman et al. (2015), the local political challenges that limit the efficiency and impact of these organizations often relate to local government inefficiency and lack of capacity, which can undermine the main objectives of community-based organization building. In addition to these organizations, community members also adopt other ways of accessing capital assets, such as taking loans from peers and relatives, micro finance organizations, government banks, or selling liquid assets, mortgaging and selling land property (Monwar et al., 2014; Kamal et al., 2018; Rahman et al., 2018c).

While having access to different assets is considered critical to diversifying rural livelihoods (Bebbington, 1999; Rakodi, 1999; Ellis, 2000; Fang et al., 2014), Rahman et al. (2018c) note that while access is necessary, is not sufficient for livelihood diversification in the northeastern floodplain region. Building on the SRL framework, they suggest that rural households combine, transform and substitute available assets in order to create different livelihood activities. While access to financial capital is one of the major stimuli of adaptation (Kamal et al., 2018), loans will not always result in successful adaptation. For example, Mallick (2012) showed that tight return schedules and high interest rates may lead rural households into a loan trap, indicating a potential path-dependency associated with this adaptation strategy which can rebound vulnerability (Barnett and O’Neill, 2010; Juhola et al., 2016). Further, Rahman et al. (2018c) identified that financial loans, when invested in land use-based livelihood activities, may be subjected to climate change impacts, and may increase socio-economic opportunity costs, eroding the endurance of adaptation strategies (Barnett and O'Neill, 2010; Juhola et al., 2016). 
Community members also follow other strategies to avoid maladaptive strategies. For example, relatively poorer and smallscale farming community members can liquefy fixed assets like land property to help cover the cost of obtaining non-natural resource dependent employment in urban areas, which tends to be more financially profitable and less uncertain than farming (Gray and Mueller, 2012; Rahman et al., 2018c). However, access to these employment markets often require different social networks, which the community members maintain through their peer and kin networks (Rahman et al., 2018c). Other ways of diversifying livelihood activities include intensifying and extensifying natural resource use. For example, some community members, who own suitable lands, can cultivate short-rotation crops to avoid the early flashflood risk of crop failure. Others will extensify their resource use through fisheries and collecting wild edible foods (Anik and Khan, 2012; Rahman et al., 2018c). However, as noted by Rahman et al. (2018c), the effectiveness of livelihood diversification as an autonomous adaptation approach, will depend on the external supports offered by broader market mechanisms (e.g., labor or produce markets) or from the national government's policy and planning support mechanisms.

\section{LEARNING FROM AUTONOMOUS ADAPTATION TO INFORM PLANNED ADAPATATION}

Despite the government's policy interventions and affected communities' responses, there remains a disconnection between policy-driven adaptation plans and the affected community's adaptation practices in northeastern Bangladesh. Such disconnects can perhaps be explained by highlighting the differences between the vulnerability framings being used by government agencies in contrast to the affected communities. For example, the design of national adaptation projects and the activities being taken under different adaptation plans demonstrate that the Bangladesh government's interventions are built upon future climate change scenarios and predicted sectoral impacts of climate change. Therefore, the adaptation actions adopted tend to be technocentric and closely related to institutional capacity building. In contrast, the affected communities are strategizing their adaptation actions building on socio-economic, social-ecological and experiential realities which are often context specific (O'Brien et al., 2007). Both of these approaches have relative advantages and disadvantages in terms of avoiding or embracing maladaptation (Engle, 2011). For example, by being context specific and local innovationbased, autonomous adaptation can help minimize the perceived impacts of climate change using local resources (Mog, 2006; Fazey et al., 2010). However, autonomous adaptation actions taken by one individual or community can also shift climate vulnerability to others. Planned adaptation, in contrast, tends to be broad-based and problem oriented (e.g., building flood protection infrastructure). However, planned adaptation can also deleteriously affect local innovation-based autonomous adaptation, making the overall adaptation process more dependent on external resources and potentially maladaptive
(Thorn et al., 2015). Therefore, as suggested by Engle (2011), in what follows we argue for a "two-way" learning approach for adaptation planning and policy in Bangladesh.

To compare planned and autonomous adaptation processes and to specifically note the potential for learning from autonomous adaptation, we organize the following discussion according to the policy themes of institutional development, resource availability and use, and the use of technologies for adaptation actions (Table 1). Like many other countries, the institutional process of national policy making in Bangladesh tend to be centralized and hierarchical, and therefore prone to problems with generalization and limited information that inspires more linear and outcome-based interpretations of vulnerability (Paul, 1997; Choudhury et al., 2004; Rahman and Hickey, 2019). However, public participation is one of the technical mandates of the COP-guided adaptation planning process, a process that the Bangladesh government strictly followed when developing the NAPA. Notably, COPguided adaptation processes were decided and prioritized at the international level, based on political negotiation among the parties. For example, the NAPA planning process emphasized identifying "immediate and priority" adaptation activities involving community participation. However, such planning processes require strong and readily-available scientific knowledge which was not the case in the northeastern floodplain and, as of 2018, it remained the most understudied region in the country (Rahman et al., 2018a). Moreover, community participation in national adaptation planning processes have generally aimed to help define climate vulnerability, rather than focusing on how the affected communities were autonomously adapting to vulnerability (Ayers J. et al., 2014). As a consequence, most of the adaptation projects implemented under national plans are heavily dependent on external inputs and technologies (Rahman and Hickey, 2019). Bezuneh et al. (1995), Mog (2006), and Fazey et al. (2010) noted that external input-dependent adaptation actions generally require heavy government subsidies and can reduce local innovation capacity, eroding the potential for sustainable adaptation. In contrast, community-based organizations tend to generate adaptation opportunities by providing access to credit and technologies (Table 1), offering a potential opportunity to support planned adaptation strategies through local knowledge and innovation processes that are less uncertain and more locally connected.

Another maladaptation risk relates to the sector-specific focus of national development plans in Bangladesh, which subsequently lack a holistic understanding of resource use dynamics and social-ecological system-level vulnerability. For example, the MPHA was designed at a more local level, yet kept the tradition of sector-specific action planning intact [Ministry of Water Resources (MoWR), 2012]. As a result, actions taken to facilitate agricultural land use (e.g., embankment building) is negatively affecting fisheries ecosystems (Megh and Najnin, 2011). Moreover, if recognized power asymmetries, socioeconomic disparities, and inefficiencies in local government are not carefully addressed, development plans may incentivize local elites to capture public investments for private gain (e.g., elites controlling the technological supports provided by government), 
TABLE 1 | Learning from autonomous adaptation to inform planned adaptation in the northeastern floodplain of Bangladesh.

\begin{tabular}{ll}
\hline Criteria & Planned adaptation \\
\hline Institutions & - \\
& Most of the planned actions are \\
& agreements \\
- & Mainstreaming climate adaptation in national \\
& development policies is one of the key \\
& institutional responses to climate vulnerability \\
- & Local levels of government agencies \\
& disseminate low cost technologies and \\
& agricultural inputs among affected people
\end{tabular}

Autonomous adaptation

\section{Implication of learning from autonomous} adaptation

- Community-based organizations are developed for generating adaptation opportunities

- Community-based organizations help to secure credit and gain access to government incentives (e.g., subsidized agricultural inputs and technologies, getting fishing rights)

- Community members maintain informal networks to secure jobs in both urban areas and sometimes abroad

- Engaging communities in order to share and understand local adaptation and innovation processes could help inform policy and practice at local levels

- Planned adaptation requires sound scientific knowledge but also local knowledge

- Resource management and use policies should be revised to make them better connected, holistic and system-based rather than sector specific

- Community-based organizations should be brought into the center of capacity building efforts (e.g., access to government support, promoting community innovation)

\begin{tabular}{ll}
\hline Resources & - \\
mechancial resources come from external \\
funding and also from the government's \\
national development funds to be used for \\
sector-specific adaptation actions \\
- Knowledge resources are mostly based on \\
scientific knowledge, broad-based, and \\
impact driven \\
- \\
Enhancing productivity of rice is one of the \\
dominant strategies
\end{tabular}

- Financial and other useable physical resources are sourced from within and outside the communities

- Knowledge and non-physical resources (e.g., social networks, local knowledge, and practices) tend to be locally generated, given that some of these resources also come from government and non-government agencies

- Use of resources like fisheries depends on government approval and resource management policies

- Communities organize, transform and/or substitute different resources to diversify their livelihood practices

\begin{tabular}{ll}
\hline $\begin{array}{l}\text { Technology } \\
\text { and }\end{array}$ & The government's planned adaptation \\
infrastructure & actions require intensive use of technology \\
& and aim to develop 'hard' infrastructure (e.g., \\
& flood infrastructure building like \\
& embankment, sluice gates, culverts etc.). \\
& Some infrastructure is having long-term \\
& negative consequences on local geography \\
& and ecosystems \\
- & Planned adaptation promotes small-scale \\
& modern technology use for agricultural \\
& expansion through subsidization (e.g., \\
& subsidized tractors, harvesters, threshers \\
& etc.)
\end{tabular}

- Communities use a mixture of local and modern technologies for both agriculture and fishing (e.g., tractor use for ploughing the land and harvesting crops manually, using different types of fishing nets other than traditional)

- Lack of knowledge about the long-term negative impacts of some technology use may cause serious ecological degradation (e.g., extensive use of chemical fertilizers and pesticides degrades fish habitat)
- Internal resources (e.g., community-based organizations, local knowledge base) should be sustained by enhancing their capacities and accessibility

- Alternative and diversified community resource uses should be a policy focus rather than emphasizing sector-specific productivity which shifts the vulnerability to local poor and marginalized groups. For example, Rahman et al. (2018c), Rahman et al. (2015), Khan and Haque (2010), and Megh and Najnin (2011) have noted that the wetland fisheries sector in the northeastern floodplain is broadly operating under elite capture, enabled in part by the national government's fisheries policy and the inefficiency of local government, limiting the access of poorer households to fishing and agricultural irrigation. While the government aims at protecting agriculture-the largest livelihood generating sector in the region-from flood risks, the community members are using their physical (e.g., land, equipment) and non-physical assets (e.g., social networks, knowledge) to diversify their livelihood activities either within their local system or in urban areas (Gray and Mueller, 2012; Rahman et al., 2018c). It may therefore be useful for the government's planned adaptation strategies to focus more on community capacity building to support livelihood diversification in both natural resource and non-natural resource-dependent sectors by, for example, providing information and creating enabling environments for new social networks to form.

Extensive use of engineered and technological solutions without building connectivity between nationally planned adaptation and autonomous local adaptation can also increase climate vulnerability. In the northeastern floodplain, the path-dependent and expensive structural solution-based flood protection strategy of the national government (e.g., embankment building, riverbed drainage) is increasing future flood potential at local scales (Brown and Nicholls, 2015; Rahman et al., 2018b). Moreover, the resulting rate of silt deposition has the potential to convert a normal flood regime to a flood stress for communities (Rahman et al., 2018b). Community members acknowledge this change, and are shifting their land use practices 
accordingly by, for example, cultivating short-rotation crops and diversifying crop varieties on suitable land (Anik and Khan, 2012; Rahman et al., 2018c). However, the government plans are not aiming to support such local interventions, rather emphasizing the potential for external input-based innovation (e.g., adoption of potato cultivation) (Rahman and Hickey, 2019). Therefore, the planned adaptation strategies may actually undermine local adaptation potential if more local autonomous adaptations go unnoticed (Fazey et al., 2010).

We recognize that tracking local adaptation dynamics in a changing social-ecological system is no easy task. It would require a well-established knowledge infrastructure capable of acquiring and organizing both scientific and local land use knowledge. Building knowledge infrastructure could be a starting point to facilitate centralized learning from communitylevel autonomous adaptation. This knowledge infrastructure could involve synthesizing both scientific and local knowledgebased adaptation innovations and practices in order to create a knowledge base capable of informing more systematic evaluations of what is suitable adaptation and what is maladaptive in such a rapidly changing social and ecological system.

\section{CONCLUSION}

Climate adaptation is an innovative and evolving process. Engaging diverse sources of innovation can serve both society and government with effective and practical adaptation options. However, planned adaptation processes, particularly in developing countries, often keep local "grassroots" innovations unacknowledged, instead depending on externally developed knowledge and technologies. As a result, many planned adaptation interventions tend to end with maladaptive outcomes. This review aimed to highlight the importance of this issue to public adaptation policy using the case of adaptation planning in the northeastern floodplain region of Bangladesh to highlight some of the flaws of contextually disconnected adaptation

\section{REFERENCES}

Adger, N. W., Arnell, N. W., and Tompkins, E. L. (2005). Successful adaptation to climate change across scales. Glob. Environ. Change 15, 77-86. doi: 10.1016/j.gloenvcha.2004.12.005

Adri, N., and Simon, D. (2017). A tale of two groups: focusing on the differential vulnerability of "climate-induced" and "non-climate-induced" migrants in Dhaka City. Clim. Dev. 10, 321-336. doi: 10.1080/17565529.2017.1291402

Ahmed, I., Deaton, B. J., Sarker, R., and Virani, T. (2008). Wetland ownership and management in a common property resource setting: a case study of Hakaluki Haor in Bangladesh. Ecol. Econ. 68, 429-436. doi: 10.1016/j.ecolecon.2008.04.016

Ahmed, M. R., Rahaman, K. R., Kok, A., and Hassan, Q. K. (2017). Remote sensing-based quantification of the impact of flash flooding on the rice production: a case study over Northeastern Bangladesh. Sensors 17:E2347. doi: $10.3390 /$ s17102347

Ahmed, Q. A., and Ahmed, A. U. (2003). "Regional cooperation in flood management in the Ganges Brahmaputra-Meghna Region: Bangladesh perspective," in Flood Problem and Management in South Asia, eds M. M. Q. Mirza, A. Dixit, and A. Nishat (Dordrecht: Springer), 181-198. plans and inform how planned adaptation processes might benefit from paying closer attention to autonomous adaptation processes.

The analysis highlights that adaptation actions taken at national and local levels are designed based on the vulnerability framing approach of both the government and the affected communities, respectively. Due to the Bangladesh government's high dependence on the scientific framing of vulnerability assessment, most adaptation actions tend to be directed toward more path-dependent engineered and structural solutions. Such actions are likely rebounding local climate vulnerability. By focusing on land use-based rural livelihoods, this review illustrates how more integrative approaches might serve to improve the identification and selection of adaptation options and, in turn, improve rural livelihood outcomes. We recognize that not all local autonomous adaptation strategies are successful, with some of these actions also likely to result in maladaptation. It is in this space that planned adaptation can play a crucial role by providing the affected communities with appropriate incentives and information to help facilitate coordination and the successful use of their livelihood assets. To this end, adaptation planning would benefit from a greater focus on learning and scrutinizing the autonomous adaptation of communities to climate stress before making significant resource allocation decisions.

\section{AUTHOR CONTRIBUTIONS}

$\mathrm{HR}$ and GH have materially participated in the research presented in this manuscript. HR led the writing of this review article, with GH co-writing sections of the paper. HR and GH have approved the final manuscript.

\section{ACKNOWLEDGMENTS}

We would like to thank Dr. Amaia Albizua, McGill University for providing valuable comments on an earlier draft of this manuscript.
Ahsan, R., Karuppannan, S., and Kellett, J. (2011). Climate migration and urban planning system: a study of Bangladesh. Environ. Justice 4, 163-170. doi: 10.1089/env.2011.0005

Alam, G. M. (2017). Livelihood cycle and vulnerability of rural households to climate change and hazards in Bangladesh. Environ. Manage. 59, 777-791. doi: 10.1007/s00267-017-0826-3

Alam, K., Shamsuddoha, M., Tanner, T., Sultana, M., Huq, M. J., and Kabir, S. S. (2011). The political economy of climate resilient development planning in Bangladesh. IDS Bull. 42, 52-61. doi: 10.1111/j.1759-5436.2011.00 222.x

Alauddin, M., and Sarker, M. A. R. (2014). Climate change and farm-level adaptation decisions and strategies in drought-prone and groundwaterdepleted areas of Bangladesh: an empirical investigation. Ecol. Econ. 106, 204-213. doi: 10.1016/j.ecolecon.2014.07.025

Ali, A. (1999). Climate change impacts and adaptation assessment in Bangladesh. Clim. Res. 12, 109-116. doi: 10.3354/cr012109

Anik, S. I., and Khan, M. A. S. A. (2012). Climate change adaptation through local knowledge in the north eastern region of Bangladesh. Mitig. Adapt. Strateg. Global Change 17, 879-896. doi: 10.1007/s11027-0119350-6 
Ayers, J., Huq, S., Wright, H., Faisal, A. M., and Hussain, S. T. (2014). Mainstreaming climate change adaptation into development in Bangladesh. Clim. Dev. 6, 293-305. doi: 10.1080/17565529.2014.977761

Ayers, J. M., and Huq, S. (2009). Supporting adaptation to climate change: what role for official development assistance?. Dev. Policy Rev. 27, 675-692. doi: 10.1111/j.1467-7679.2009.00465.x

Ayers, J. M., Huq, S., Faisal, A. M., and Hussain, S. T. (2014). Mainstreaming climate change adaptation into development: a case study of Bangladesh. Wiley Interdiscipl. Rev. Clim. Change 5, 37-51. doi: 10.1002/wcc.226

Barnett, J. (2003). Security and climate change. Global Environ. Change 13, 7-17. doi: 10.1016/S0959-3780(02)00080-8

Barnett, J., and Adger, W. N. (2007). Climate change, human security and violent conflict. Polit. Geogr. 26, 639-655. doi: 10.1016/j.polgeo.2007.03.003

Barnett, J., and O'Neill, S. (2010). Maladaptation. Global Environ. Change 20, 211-213. doi: 10.1016/j.gloenvcha.2009.11.004

Bebbington, A. (1999). Capitals and capabilities: a framework for analyzing peasant viability, rural livelihoods and poverty. World Dev. 27, 2021-2044. doi: 10.1016/S0305-750X(99)00104-7

Begum, S., and Fleming, G. (2009). Climate change and sea level rise in Bangladesh, part I: numerical simulation. Mar. Geod. 20, 33-53. doi: 10.1080/01490419709388093

Bele, M. Y., Tiani, A. M., Somorin, O. A., and Sonwa, D. J. (2013). Exploring vulnerability and adaptation to climate change of communities in the forest zone of Cameroon. Clim. Change 119, 875-889. doi: $10.1007 / \mathrm{s} 10584-013-0738-z$

Bezuneh, M., Ames, G. C. W., and Mabbs-Zeno, C. C. (1995). Sustainable agricultural development using a farming systems approach in Zambia. Ecol. Econ. 15, 149-156. doi: 10.1016/0921-8009(95)00042-9

Bidwell, D., Dietz, T., and Scavia, D. (2013). Fostering knowledge networks for climate adaptation. Nat. Clim. Change 3, 610-611. doi: 10.1038/nclimate1931

Brown, S., and Nicholls, R. J. (2015). Subsidence and human influences in mega deltas: the case of the Ganges-Brahmaputra-Meghna. Sci. Total Environ. 527-528, 362-374. doi: 10.1016/j.scitotenv.2015.04.124

Burton, I., Huq, S., Lim, B., Pilifosova, O., and Schipper, E. L. (2002). From impacts assessment to adaptation priorities: the shaping of adaptation policy. Clim. Policy 2, 145-159. doi: 10.3763/cpol.2002.0217

Cash, D., Clark, W. C., Alcock, F., Dickson, N., Eckley, N., and Jäger, J. (2002). "Salience, credibility, legitimacy and boundaries: linking research, assessment and decision making," in John F. Kennedy School of Government, Harvard University, Faculty Research Working Papers Series (Boston, MA: John F. Kennedy School of Government, Harvard University).

Chambers, R. (2006). Vulnerability, coping and policy (editorial introduction). IDS Bull. 37, 33-40. doi: 10.1111/j.1759-5436.2006.tb00284.x

Choudhury, G. A., and Nishat, A. (2005). Hydro-Meteorological Characteristics of Hakaluki Haor. Dhaka: IUCN Bangladesh Country Office.

Choudhury, N. Y., Paul, A., and Paul, B. K. (2004). Impact of costal embankment on the flash flood in Bangladesh: a case study. Appl. Geogr. 24, 241-258. doi: 10.1016/j.apgeog.2004.04.001

Cinner, J. E., and Bodin, O. (2010). Livelihood diversification in tropical coastal communities: a network-based approach to analyzing 'livelihood landscapes'. PLoS ONE 5:e11999. doi: 10.1371/journal.pone.0011999

Cinner, J. E., McClanahan, T. R., Graham, N. A. J., Daw, T. M., Maina, J., Stead, S. M., et al. (2012). Vulnerability of coastal communities to key impacts of climate change on coral reef fisheries. Global Environ. Change 22, 12-20. doi: 10.1016/j.gloenvcha.2011.09.018

Ellis, F. (2000). Rural Livelihoods and Diversity in Developing Countries. New York, NY: Oxford University Press.

Engle, N. L. (2011). Adaptive capacity and its assessment. Global Environ. Change 21, 647-656. doi: 10.1016/j.gloenvcha.2011.01.019

Etzold, B., Ahmed, A. U., Hassan, S. R., and Neelormi, S. (2013). Clouds gather in the sky, but no rain falls. Vulnerability to rainfall variability and food insecurity in Northern Bangladesh and its effects on migration. Clim. Dev. 6, 18-27. doi: 10.1080/17565529.2013.833078

Fang, Y.-P., Fan, J., Shen, M.-Y., and Song, M.-Q. (2014). Sensitivity of livelihood strategy to livelihood capital in mountain areas: empirical analysis based on different settlements in the upper reaches of the Minjiang River, China. Ecol. Indic. 38, 225-235. doi: 10.1016/j.ecolind.2013.11.007
Fankhauser, S., Smith, J. B., and Tol, R. S. J. (1999). Weathering climate change: some simple rules to guide adaptation decisions. Ecol. Econ. 30, 67-78. doi: 10.1016/S0921-8009(98)00117-7

Fazey, I., Gamarra, J. G. P., Fischer, J., Reed, M. S., Stringer, L. C., and Christie, M. (2010). Adaptation strategies for reducing vulnerability to future environmental change. Front. Ecol. Environ. 8, 414-422. doi: 10.1890/080215

Ford, J. D., Knight, M., and Pearce, T. (2013). Assessing the 'usability' of climate change research for decision-making: a case study of the Canadian International Polar Year. Global Environ. Change 23, 1317-1326. doi: 10.1016/j.gloenvcha.2013.06.001

Frank, E., Eakin, H., and López-Carr, D. (2011). Social identity, perception and motivation in adaptation to climate risk in the coffee sector of Chiapas, Mexico. Glob. Environ. Change 21, 66-76. doi: 10.1016/j.gloenvcha.2010.11.001

Füssel, H., and Klein, R. J. T. (2006). Climate change vulnerability assessment: an evolution of conceptual thinking. Clim. Change 75, 301-329. doi: 10.1007/s10584-006-0329-3

Füssel, H. M. (2007). Adaptation planning for climate change: concepts, assessment approaches, and key lessons. Sustain. Sci. 2, 265-275. doi: 10.1007/s11625-007-0032-y

Gray, C. L., and Mueller, V. (2012). Natural disasters and population mobility in Bangladesh. Proc. Natl. Acad. Sci. U.S.A. 109, 6000-6005. doi: 10.1073/pnas.1115944109

Haq, S. M. A., and Ahmed, K. J. (2016). Does the perception of climate change vary with the socio-demographic dimensions? A study on vulnerable populations in Bangladesh. Nat. Hazards 85, 1759-1785. doi: 10.1007/s11069-016-2664-7

Haque, A., and Jahan, S. (2015). Impact of flood disasters in Bangladesh: a multi-sector regional analysis. Int. J. Disaster Risk Reduct. 13, 266-275. doi: 10.1016/j.ijdrr.2015.07.001

Haque, M. M., Bremer, S., Aziz, S. B., and van der Sluijs, J. P. (2017). A critical assessment of knowledge quality for climate adaptation in Sylhet Division, Bangladesh. Clim. Risk Manage. 16, 43-58. doi: 10.1016/j.crm.2016.12.002

Hasan, G. M. J., Chowdhury, M. A. I., and Ahmed, S. (2014). Analysis of the statistical behavior of daily maximum and monthly average rainfall along with rainy days variation in Sylhet, Bangladesh. J. Eng. Sci. Technol. 9, 559-578. Available online at: http://jestec.taylors.edu.my/Vol\%209\%20Issue \%205\%20October\%2014/Volume\%20(9)\%20Issue\%20(5)\%20559-578.pdf

Hassani-Mahmooei, B., and Parris, B. W. (2012). Climate change and internal migration patterns in Bangladesh: an agent-based model. Environ. Dev. Econ. 17, 763-780. doi: 10.1017/S1355770X12000290

Hossain, A., and Teixeira da Silva, J. A. (2013). Wheat production in Bangladesh: its future in the light of global warming. AoB Plants 5:pls042. doi: 10.1093/aobpla/pls042

Huq, S., and Rabbani, G. (2011). Climate change and Bangladesh: policy and institutional development to reduce vulnerability. J. Bangladesh Stud. 13, 1-10. Available online at: https://www.researchgate.net/profile/Rabbani/publication/ 251571877_Climate_Change_and_Bangladesh_Policy_and_Institutional_ Development_to_reduce_vulnerability/links/0046351fofc3387310000000/ Climate-Change-and-Bangladesh-Policy-and-Institutional-Development-toreduce-vulnerability.pdf

IPCC (2007). Climate Change 2007: Synthesis Report. Contribution of Working Groups I, II and III to the Fourth Assessment Report of the Intergovernmental Panel on Climate Change. Cambridge: Cambridge University Press.

IPCC (2012). Managing the Risks of Extreme Events and Disasters to Advance Climate Change Adaptation. Cambridge: Cambridge University Press.

IPCC (2014). Climate Change 2014: Impacts, Adaptation and Vulnerability. Part A: Global and Sectoral Aspects. Contribution of Working Group II to the Fifth Assessment Report of the Inter-Governmental Panel on Climate Change. Cambridge: Cambridge University Press.

Islam, M. M., Sallu, S., Hubacek, K., and Paavola, J. (2014). Migrating to tackle climate variability and change? Insights from coastal fishing communities in Bangladesh. Clim. Change 124, 733-746. doi: 10.1007/s10584-014-1135-y

Islam, M. R. (2017). Climate change, natural disasters and socioeconomic livelihood vulnerabilities: migration decision among the Char land people in Bangladesh. Soc. Indic. Res. 136, 575-593. doi: 10.1007/s11205-0171563-y

Johnson, S. Y., and Alam, A. M. N. (1991). Sedimentation and tectonics of the Sylhet trough, Bangladesh. Geol. Soc. Am. Bull. 103:1513. 
Juhola, S., Glaas, E., Linnér, B.-O., and Neset, T.-S. (2016). Redefining maladaptation. Environ. Sci. Policy 55, 135-140. doi: 10.1016/j.envsci.2015.09.014

Jurgilevich, A., Räsänen, A., Groundstroem, F., and Juhola, S. (2017). A systematic review of dynamics in climate risk and vulnerability assessments. Environ. Res. Lett. 12, 1-15. doi: 10.1088/1748-9326/aa5508

Kamal, A. S. M. M., Shamsudduha, M., Ahmed, B., Hassan, S. M. K., Islam, M. S., Kelman, I., et al. (2018). Resilience to flash floods in wetland communities of northeastern Bangladesh. Int. J. Disaster Risk Reduct. 31, 478-488. doi: 10.1016/j.ijdrr.2018.06.011

Karim, M., and Mimura, N. (2008). Impacts of climate change and sea-level rise on cyclonic storm surge floods in Bangladesh. Glob. Environ. Change 18, 490-500. doi: 10.1016/j.gloenvcha.2008.05.002

Karim, M. R., Ishikawa, M., and Ikeda, M. (2012). Modeling of seasonal water balance for crop production in Bangladesh with implications for future projection. Italian J. Agron. 7:e21. doi: 10.4081/ija.2012.e21

Kartiki, K. (2011). Climate change and migration: a case study from rural Bangladesh. Gender Dev. 19, 23-38. doi: 10.1080/13552074.2011.554017

Kay, S., Caesar, J., Wolf, J., Bricheno, L., Nicholls, R. J., Saiful Islam, A. K., et al. (2015). Modelling the increased frequency of extreme sea levels in the GangesBrahmaputra-Meghna delta due to sea level rise and other effects of climate change. Environ. Sci. Process Impacts 17, 1311-1322. doi: 10.1039/C4EM00683F

Khan, S. M. M. H., and Haque, C. E. (2010). Wetland resource management in Bangladesh: implications for marginalization and vulnerability of local harvesters. Environ. Hazards 9, 54-73. doi: 10.3763/ehaz.2010.SI08

Lalor, B. M., and Hickey, G. M. (2014). Strengthening the role of science in the environmental decision-making processes of executive government. Organ. Environ. 27, 161-180. doi: 10.1177/1086026614525641

Lemos, M. C., Kirchhoff, C. J., and Ramprasad, V. (2012). Narrowing the climate information usability gap. Nat. Clim. Change 2, 789-794. doi: $10.1038 /$ nclimate1614

Magnan, A. K., Schipper, E. L. F., Burkett, M., Bharwani, S., Burton, I., Eriksen, S., et al. (2016). Addressing the risk of maladaptation to climate change. Wiley Interdiscipl. Rev. Clim. Change 7, 646-665. doi: 10.1002/wcc.409

Malik, A., Qin, X., and Smith, S. C. (2010). Autonomous Adaptation to Climate Change: A Literature Review. Washington, DC: Elliott School of International Affairs, George Washington University.

Mallick, D. (2012). Microfinance and moneylender interest rate: evidence from Bangladesh. World Dev. 40, 1181-1189. doi: 10.1016/j.worlddev.2011. 12.011

Masood, M., and Takeuchi, K. (2016). Climate change impacts and its implications on future water resource management in the Meghna Basin. Futures 78-79, 1-18. doi: 10.1016/j.futures.2016.03.001

Megh, S. M., and Najnin, A. (2011). "Participatory planning approach for managing flash flood and conserving the natural environment in 37 Haors of North Eastern region of Bangladesh," in 11th International Congress of Asian Planning Schools Association, ed Y. Nishimura (Tokyo: APSA).

Miah, M. D., Kabir, M. H., Koike, M., and Akther, S. (2011). Major climate-change issues covered by the daily newspapers of Bangladesh. Environmentalist 31, 67-73. doi: 10.1007/s10669-010-9305-6

Midtgaard, M. B., and Madsen, O. J. (2018). Exploring local knowledge on climate variability in Bangladesh: a cultural psychological inquiry. Hum. Arenas 1, 431-448. doi: 10.1007/s42087-018-0031-9

Ministry of Environment and Forests (MoEF) (2005). National Adaptation Programme of Action, 2005. Dhaka: Government of the People's Republic of Bangladesh.

Ministry of Planning (MoP) (2010). National Sustainable Development Strategies. Dhaka: Government of People's Republic of Bangladesh.

Ministry of Water Resources (MoWR) (2012). Master Plan of Haor Area. Dhaka: Governemnt of People's Republic of Bangladesh.

Mirza, M. M. Q. (2002). Global warming and changes in the probability ofoccurrence of floods in Bangladesh and implications. Global Environ. Change 12, 127-138. doi: 10.1016/S0959-3780(02)00002-X

MoEF (2009). Bangladesh Climate Change Strategy and Action Plan, 2009. Dhaka: Government of the People's Republic of Bangladesh.

Mog, J. M. (2006). Managing Development Programs for Sustainability: Integrating development and research through adaptive management. Soc. Nat. Resour. 19, 531-546. doi: 10.1080/08941920600663961
Monwar, M. M., Mustafa, M. G., Khan, N. A., Hossain, M. S., Hossain, M. M., Majumder, M. K., et al. (2014). Indigenous adaptation practices for the development of climate resilient ecosystems in the Hail Haor, Bangladesh. Global Soc. Welfare 5, 125-136. doi: 10.1007/s40609-014-0014-9

Morton, J. F. (2007). The impact of climate change on smallholder and subsistence agriculture. Proc. Natl. Acad. Sci. U.S.A. 104, 19680-19685. doi: 10.1073/pnas.0701855104

Nowreen, S., Murshed, S. B., Islam, A. K. M. S., Bhaskaran, B., and Hasan, M. A. (2014). Changes of rainfall extremes around the haor basin areas of Bangladesh using multi-member ensemble RCM. Theor. Appl. Climatol. 119, 363-377. doi: 10.1007/s00704-014-1101-7

Nury, A. H., Hasan, K., and Alam, M. J. B. (2017). Comparative study of wavelet-ARIMA and wavelet-ANN models for temperature time series data in northeastern Bangladesh. J. King Saud Univ. Sci. 29, 47-61. doi: $10.1016 /$ j.jksus.2015.12.002

O'Brien, K., Eriksen, S., Nygaard, L. P., and Schjolden, A. N. E. (2007). Why different interpretations of vulnerability matter in climate change discourses. Clim. Policy 7, 73-88. doi: 10.1080/14693062.2007.9685639

Parvin, A., and Johnson, C. (2015). "Disaster disaster vulnerability vulnerability in the policy policy context of Bangladesh: a critical review," in Handbook of Climate Change Adaptation, ed W. Leal Filho (Berlin; Heidelberg: Springer), 877-899.

Paul, B. K. (1997). Flood research in Bangladesh in retrospect and prospect: a riview. Geoforum 28, 121-131. doi: 10.1016/S0016-7185(97)00004-3

Pouliotte, J., Smit, B., and Westerhoff, L. (2011). Adaptation and development: livelihoods and climate change in Subarnabad, Bangladesh. Clim. Dev. 1, 31-46. doi: 10.3763/cdev.2009.0001

Rabbani, G., Rahman, S., and Faulkner, L. (2013). Impacts of climatic hazards on the small wetland ecosystems (ponds): evidence from some selected areas of coastal Bangladesh. Sustainability 5, 1510-1521. doi: 10.3390/su504 1510

Rahman, H. M. T., and Hickey, G. M. (2019). Assessing Institutional Responses to Climate Change Impacts in the North-Eastern Floodplains of Bangladesh. Environ. Manage. Forthcoming.

Rahman, H. M. T., Hickey, G. M., Ford, J. D., and Egan, M. A. (2018a). Climate change research in Bangladesh: research gaps and implications for adaptation-related decision-making. Region. Environ. Change 18, 1535-1553. doi: 10.1007/s10113-017-1271-9

Rahman, H. M. T., Hickey, G. M., and Sarker, S. K. (2012). A framework for evaluating collective action and informal institutional dynamics under a resource management policy of decentralization. Ecol. Econ. 83, 32-41. doi: 10.1016/j.ecolecon.2012.08.018

Rahman, H. M. T., Hickey, G. M., and Sarker, S. K. (2015). Examining the role of social capital in community collective action for sustainable wetland fisheries in Bangladesh. Wetlands 35, 487-499. doi: 10.1007/s13157-015-0635-5

Rahman, H. M. T., Mia, M. E., Ford, J. D., Robinson, B. E., and Hickey, G. M. (2018b). Livelihood exposure to climatic stresses in the northeastern floodplains of Bangladesh. Land Use Policy 79, 199-214. doi: 10.1016/j.landusepol.2018.08.015

Rahman, H. M. T., Robinson, B. E., Ford, J. D., and Hickey, G. M. (2018c). How do capital asset interactions affect livelihood sensitivity to climatic stresses? insights from the northeastern floodplains of Bangladesh. Ecol. Econ. 150, 165-176. doi: 10.1016/j.ecolecon.2018.04.006

Rahman, H. M. T., Sarker, S. K., Hickey, G. M., Mohasinul Haque, M., and Das, N. (2014). Informal institutional responses to government interventions: lessons from Madhupur National Park, Bangladesh. Environ. Manage. 54, 1175-1189. doi: 10.1007/s00267-014-0325-8

Rahman, M. H., Fardusi, M. J., Roy, B., and Raihan, F. (2011). Unplanned urbanization and hill cutting: a study on environmental change in Sylhet. BRAC Univ. J. VIII, 13-21. Available online at: http://hdl.handle.net/10361/1800

Rai, N., Huq, S., and Huq, M. J. (2014). Climate resilient planning in Bangladesh: a review of progress and early experiences of moving from planning to implementation. Dev. Pract. 24, 527-543. doi: 10.1080/09614524.2014.90 8822

Rajib, M., and Rahman, M. (2012). A comprehensive modeling study on Regional Climate Model (RCM) application - regional warming projections in monthly resolutions under IPCC A1B scenario. Atmosphere 3, 557-572. doi: $10.3390 /$ atmos 3040557 
Rakodi, C. (1999). A capital assets framework for analysing household livelihood strategies: implications for policy. Dev. Policy Rev. 17, 315-342. doi: 10.1111/1467-7679.00090

Rawlani, A. K., and Sovacool, B. K. (2011). Building responsiveness to climate change through community based adaptation in Bangladesh. Mitig. Adapt. Strateg. Global Change 16, 845-863. doi: 10.1007/s11027-011-9298-6

Ribot, J. (2014). Cause and response: vulnerability and climate in the Anthropocene. J. Peasant Stud. 41, 667-705. doi: $10.1080 / 03066150.2014 .894911$

Rodima-Taylor, D., Olwig, M. F., and Chhetri, N. (2012). Adaptation as innovation, innovation as adaptation: an institutional approach to climate change. Appl. Geogr. 33, 107-111. doi: 10.1016/j.apgeog.2011.10.011

Safi, A. S., Smith, W. J. Jr., and Liu, Z. (2012). Rural Nevada and climate change: vulnerability, beliefs, and risk perception. Risk Anal. 32, 1041-1059. doi: 10.1111/j.1539-6924.2012.01836.x

Sánchez-Cortés, M. S., and Chavero, E. L. (2010). Indigenous perception of changes in climate variability and its relationship with agriculture in a Zoque community of Chiapas, Mexico. Clim. Change 107, 363-389. doi: $10.1007 /$ s10584-010-9972-9

Shahid, S., and Behrawan, H. (2008). Drought risk assessment in the western part of Bangladesh. Nat. Hazards 46, 391-413. doi: 10.1007/s11069-007-9191-5

Shahid, S., and Khairulmaini, O. S. (2009). Spatio-temporal variability of rainfall over Bangladesh during the time period 1969-2003. Asia Pacific J. Atmos. Sci. 43, 375-389. Available online at: https://ssrn.com/abstract $=1674429$

Smit, B., Burton, I., Klein, R. J. T., and Wandel, J. (2000). An anatomy of adaptation to climate change and variability. Clim. Change 45, 223-251. doi: 10.1023/A:1005661622966

Smit, B., and Wandel, J. (2006). Adaptation, adaptive capacity and vulnerability. Glob. Environ. Change 16, 282-292. doi: 10.1016/j.gloenvcha.2006.03.008

Szabo, S., Hajra, R., Baschieri, A., and Matthews, Z. (2016). Inequalities in human well-being in the urban Ganges Brahmaputra Meghna Delta. Sustainability 8:608. doi: $10.3390 /$ su 8070608
Tashmin, N. (2016). Can climate finance in Bangladesh be helpful in making transformational change in ecosystem management? Environ. Syst. Res. 5:2. doi: $10.1186 / s 40068-016-0054-5$

Thorn, J., Thornton, T. F., and Helfgott, A. (2015). Autonomous adaptation to global environmental change in peri-urban settlements: evidence of a growing culture of innovation and revitalisation in Mathare Valley Slums, Nairobi. Global Environ. Change 31, 121-131. doi: 10.1016/j.gloenvcha.2014.12.009

Tompkins, E. L., and Adger, W. N. (2004). Does adaptive management of natural resources enhance resilience to climate change? Ecol. Soc. 9:10. doi: 10.5751/ES-00667-090210

Uddin, M. J., Mohiuddin, A. S. M., and Hossain, S. T. (2013). Eco-environmental changes of Hail haor wetland resources under Sylhey basin of Bangladesh due to sedimentation: a GIS approach. J. Asiatic Soc. Bangladesh Sci. 39, 125-128. doi: $10.3329 /$ jasbs.v39i1.16041

UNFCCC (2001). Guidelines for the Preparation of National Adaptation Programmes of Action. Available online at: http://unfccc.int/resource/ldc/ documents/13a04p7.pdf (Accessed October 8, 2018).

Wachinger, G., Renn, O., Begg, C., and Kuhlicke, C. (2013). The risk perception paradox-implications for governance and communication of natural hazards. Risk Anal. 33, 1049-1065. doi: 10.1111/j.1539-6924.2012. 01942.x

Conflict of Interest Statement: The authors declare that the research was conducted in the absence of any commercial or financial relationships that could be construed as a potential conflict of interest.

Copyright $\odot 2019$ Rahman and Hickey. This is an open-access article distributed under the terms of the Creative Commons Attribution License (CC BY). The use, distribution or reproduction in other forums is permitted, provided the original author(s) and the copyright owner(s) are credited and that the original publication in this journal is cited, in accordance with accepted academic practice. No use, distribution or reproduction is permitted which does not comply with these terms. 